\title{
問題討論
}

\section{對於“造紙在我國的起源和發展” 一文的一點意胃}

袁翰青先生在“科盢通報” 1954 年 12 月號上. 弡表了一箱論交“造紙在我國的起源和發展”, 裹 面敂到我的一篇關於中國紙和造紙法傅入印度的 論交。袁先生提出了不同的意見。現在把我的意 見寫在下面。

袁先生說: “紙張的傳入印度㗂當早於第七 世紀之前相當久的時日。甚至於可以大胆地推到 三、四世紀。”這自然是一偑很值得歡迎的假設。 但是可情證據不足, 甚至可以說是沟有證據。

搪我所了解的, 表先生唯一的證 據 就 是王 㗎“拾遺記”裹的一句話。我們且不談作第史料秝 看“拾遺記”究竟有多大價値, 即使我們承認逭部 書的史料僄值，這一句話也絲毫不能證明中國紙 張是在三、四世紀從海路傳到印度去的。逜句話 是: “側理紙萬番, 此南越所缺。”袁先生先肯定南
越就是現在的越南一帶。既然造一帶在沓代就能 造側理紙，也就很可能是從海路傅入印度的。湳 越究竟是什麼地方? 侧理紙究筧是什答紙? 造些 矣碎問題我們逼裹都不㓭。我們只睒一下古代越

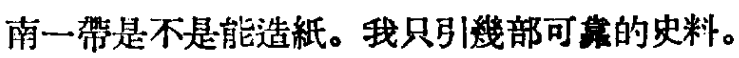
宋趙汝适“諸蓞志”: 交趾國“不能造紙筆, 求之省 地”。元汗大湭“島夷志略”: 占城 “以白字寫 黑皮 第交書”。類似的記載邆可以在許多書裹找到。不 但在現在越南一帶找不到古代能造紙的記載, 在 南洋一带也都找不到。根據我們現在能学握的中 外史料, 無論如何也得不出“中國紙張在三、四世 紀從海路傅入印度”的結論。詳細的㫴登另文討 諭。

季羡林

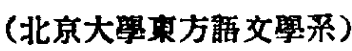

\section{關於共土丘陵區修梯田的問題}

䖯“科學通報” 1954 年 12 月號席承藩同志寫 的“在黄土丘陵區不宜大量推廣梯田”一文, 我們 有以下㙨點意見，提供給關心西北水土保持工作 的同志們䆝考。

目前傸北黄土丘弫前不準備坡坡都修梯 田, 而是在 $8-25^{\circ}$ 之間的坡地上, 用逐年培修的 辦法使其成票坡式的梯田。遭部分約佔總面 皘 $30 \%$ ，是目前當地唇尼的生活基地，是莀產的 主要來源。陝北以往梯田少、並不是單純的土質 問題, 而有它的最大㼛會因素在內, 如地大勞力 少, 農民經營不替慣等。这是過去的情况, 現在
不同了。自 1953 年蒷采和幹部參観山西本順 縣

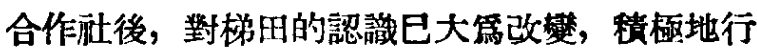
動起來。現在我們如再不去皘極推進，仍處在局 部的試驗階段，答必要落到國家和覃采需要之後 了。

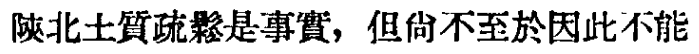
修梯田。土質疏稿踓是修梯田的不利條件，但我 們應想辦法去改造它的不利方面, 而利局它的有 利方面。土猿內含水量是否適宜, 是修梯性的重 要因素之一。一般在春季是不宜修梯田的，因篇

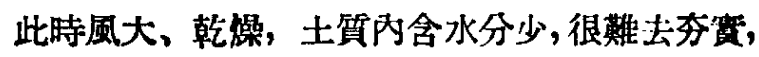

